\title{
Family Structure and Ownership of a Dog
}

\author{
Xinhe Zhang $^{1)}$, Takahiro Kozuka ${ }^{2)}$ and Koubun Wakashima ${ }^{1)}$ \\ ${ }^{1)}$ Graduate School of Education, Tohoku University \\ ${ }^{2)}$ Faculty of Human and Culture, Sakushin Gakuin University
}

\begin{abstract}
The aim of this research is to exploratorily determine how keeping a dog alters family structures. From samples collected through questionnaire papers and on the internet, 313 dog-owning families were selected as the subject for this analysis. We performed a single-factor analysis of variance (single-factor ANOVA) with the three periods of time; "Before ownership", "Immediately after ownership", and "Present", as the independent variables, and the subscales of family structure; "cohesion" between the parents, the father and children, and the mother and children, and the bidirectional "power" in each relationship as the dependent variables. We found that there was an alteration in the family structure between the time period "before ownership" and the two time periods after ownership, with a noticeable difference in the father's power over children. We discuss the relationship between the act of keeping a dog and the structure of the family.
\end{abstract}

KEY WORDS : Family structure, Dog, Pet.

\section{Introduction}

To have a dog as a member of the family has a significant role in family life. The number of dogs kept in Japan reaches 10872, the number suggesting that $15.8 \%$ of all families in Japan have a dog (Japan Pet Food Association, 2013). This number is predicted to increase to $26.8 \%$ and it has been said that the number of people willing to own a dog reaches double the number of people who currently have a dog (Japan Pet Food Association, 2013). Furthermore, over $85 \%$ of dog-owners treat their dog as a member of the family (Cohen,

CoRrespondence to ZHANG, Graduate School of Education, Tohoku University, 27-1 Kawauchi, Aoba-ku, Sendai-city, 980-8576, JAPAN.

E-mail: guhong15_qiaoxinka@yahoo.co.jp
2002). The dog is not a mere pet, but a member of the family that becomes a target of affection and attention. In Japan, with the declining birthrate and ageing population, the role of the dog in the family is thought to become more prominent.

Positive effects evoked by the ownership of a dog on the physiological, psychological, and social states of the owner have been suggested (Yokoyama, 1996). Furthermore, Wakai and Matsui (2006) suggest that owners who do not recognize a mutual affection between the dog and themselves reap little positive effect from the ownership of the dog. This suggests that mere act of keeping a dog is not sufficient, and it is the favorable relationship between the owner and the dog that evokes the positive effects on the owner. We consider what choices for the environment and the breed of the dog 
are important in creating a good relationship between the owner and the dog.

The ownership of a dog most often calls for cooperation between family members, and it is expected that this will have an impact on each member of the family in various forms. Cain (1983) suggests that pets act as "glue" in the family, bringing together family members and strengthening the bonds between each member. Froma (2009) suggests that raising a pet, as with raising children, is related to variables such as rules and roles in the family, power in the family structure, borders, clarity of communication and problem solving; thus providing the family system with an opportunity for learning and change. Paul and Serpell (1996) report that compared to children of families without a dog, children of families who own a dog receive more visits from friends and members of those families partake in leisure activities more. In Japan, according to the "Survey on Animal Welfare" conducted by the Cabinet Office in 2010, when asked the positive outcomes of owning a dog the most chosen response was "Nourishment and peace in family life" at $61.4 \%$, followed by "A calmer home environment" (55.3\%), "Enrichment of emotional well-being for children" (47.2\%), "Enjoyment of raising a dog"(31.6\%). It can be deduced from these results that owning a pet has a positive effect on family relationships. However, there is little research on how family relationships are altered through raising a dog. Our aim in this research is to comprehensively discuss what changes are observed in the family through the introduction of a dog into the family, taking into consideration basic information such as the number of dogs owned, the breed, the environment in which the dog is kept, the family member responsible for the decision to own a dog, and the main care taker for the dog.

\section{Methods}

\section{Procedures and participants}

A questionnaire survey was conducted on 385 dog-owning families nationwide. The target for this investigation is the typical family who keep dogs as a pet, not professionals who specialize in one breed, such as dog breeders. Of the responses from the 385 families, data with a high number of missing values were excluded and taking the homogeneity of the families into consideration, 313 families with children under 18 were chosen as the target for the analysis. The questionnaire was distributed on the internet and through veterinary clinics across the Tohoku region and data was collected by mail. In addition, we requested ordinary families to complete a survey and collected the data by mail.

\section{Measures}

\section{Basic information}

Age and gender of the participant, family members living together, form of residence (house, apartment, flat), area of residence (suburbs, housing districts, city centers), number of dogs owned, breed and age of the dog, number of dogs owned in the past, keeping environment (indoors or outdoors), the family member who decided to own a dog, the main 
care taker for the dog.

2. ICHIGEKI (Noguchi, Kozuka, Usami, \& Wakashima, 2009)

Assessment of the relationship between family members (between parents, father and children, mother and children) as single items. In our research, out of the four factors suggested in ICHIGEKI,;"cohesion", "interests in relationship", "power", "openness", we adopted for simplicity the two factors; "cohesion" and "power" as the main factors in the assessment of family relationship.

\section{Results}

\section{Basic information}

First we will describe the general trend in the basic information about the family, residence and the dog.

The average age of the participant was 43.06 $(S D=5.70) .105$ participants $(34 \%)$ were male (the father), and 208 participants $(66 \%)$ were female (the mother). $87 \%$ of the participants were in their thirties and forties. The average age of the eldest child was $13.72(S D=3.56)$, $140(45 \%)$ were male, $173(55 \%)$ were female. This indicates that the eldest children are primarily adolescents.

Regarding the family structure, $85 \%$ were nuclear families. $48 \%$ had four family members living together, $27 \%$ with three family members. As the form of residence, $78 \%$ of the participants lived in houses, making up the majority. $60 \%$ of the participants live in housing districts, $26 \%$ in the suburbs. This shows that the general trend for this sample was nuclear families living in houses in housing districts or suburbs.

$87 \%$ of the families owned one dog, $64 \%$ owned small-breed dogs and 25\% owned medium-breeds. $72 \%$ of the families had only owned one dog until present, $81 \%$ of the families kept their dog indoors. Keeping small-breed dogs indoors was the general trend for the participating families.

For $71 \%$ of the participating families, the family member responsible for the decision to own a dog included the mother or the father, the person completing the survey (applicable for families with members other than the person completing the survey). $29 \%$ of the participants completing the survey responded that it was a different family member's decision to own a dog. For $75 \%$ of the families, the participant in the survey, the mother or the father, was the main care taker for the dog (applicable for families with members other than the person completing the survey). $25 \%$ of the participants responded that another family member was the main care taker for the dog. As a general trend, the decision to own a dog was made by the participant, the father or the mother, or a number of family members including the participant, and that same person became the main care taker for the dog in the family.

Table 1 indicates common breeds of dog owned by each family.

\section{Changes in family structure}

To consider how introducing a dog into the family changes family structure, We performed 
a single-factor analysis of variance (single-factor ANOVA) on 313 families. The independent variables were the three time periods; "Before ownership", "Immediately after ownership" and "Present". The dependent variables assessed in this analysis were "Cohesion" between the subscales of family structure; parents (mother and father), father and children, and mother and children, and the bidirectional "power" between the parents, father and children, and mother and children (Table 2).

In the results, a significant difference was observed in the following items; cohesion between the father and children $\left(F_{(2,624)}=14.06\right.$, $p<.001$ ), cohesion between the mother and children $\quad\left(F_{(2,624)}=7.51, \quad p<.01\right), \quad$ cohesion between the mother and father $\left(F_{(2,624)}=6.55\right.$, $p<.01$ ), power of the father over children $\left(F_{(2,624)}=186.50, p<.001\right)$, power of the mother over the father $\left(F_{(2,624)}=10.13, p<.001\right)$, power of the children over the father $\left(F_{(2,624)}=16.30\right.$, $p<.001$ ), power of the children over the mother $\left(F_{(2,624)}=27.64, p<.001\right)$. Multiple comparisons (Bonferroni method) revealed that cohesion between the father and children, cohesion between the mother and children, power of the father over the children and power of the mother over the father are greater for both time periods "immediately after ownership" and "present" compared to the time period "before ownership". The power of the children over the father and the power of the children over the mother are greater immediately after ownership than before, and greater in the present than the time immediately after ownership.

Table 1 Common breeds of dog owned by each family

\begin{tabular}{ll}
\hline \multicolumn{1}{c}{ Breed } & $N$ \\
\hline Mix Breed (Mongrel) & 43 \\
Miniature Dachshund & 43 \\
Toy Poodle & 35 \\
Shiba Inu & 31 \\
Chihuahua & 30 \\
Papillon & 14 \\
Labrador Retriver & 9 \\
Pomeranian & 9 \\
Shih Tzu & 8 \\
Miniature Schnauzer & 8 \\
Long-coat Chihuahua & 7 \\
\hline
\end{tabular}




\section{Discussion}

In this research, to consider the changes in family structure evoked when introducing a dog into the family, we conducted a survey on 313 families who raise dogs and assessed the alterations in family structure caused by the ownership of a dog, with consideration of basic information such as keeping environment, the family member who decided to have a dog and the main care taker for the dog. Results show that introducing a dog into the family strengthened the cohesion between each family member. The power of the children over parents, of the mother over children and most notably the power of the father over children showed significant increase.

The reason for the change in family structure, considering the keeping environment, we can assume the influence of the location; the environment of the housing district, with interrelationship with the surrounding community, and houses as the form of residence indicating the abundance of living space.

Table 2 Results for the single-factor ANOVA of family structure for three time periods

\begin{tabular}{|c|c|c|c|c|c|c|c|c|}
\hline & \multicolumn{2}{|c|}{$\begin{array}{c}\text { Before } \\
\text { Ownership } \\
\text { (BO) }\end{array}$} & \multicolumn{2}{|c|}{$\begin{array}{c}\text { Immediately } \\
\text { after } \\
\text { Ownership } \\
\text { (IO) }\end{array}$} & \multicolumn{2}{|c|}{$\begin{array}{l}\text { Present } \\
\text { (P) }\end{array}$} & \multirow[t]{2}{*}{$F$} & \multirow[t]{2}{*}{$\begin{array}{c}\text { Multiple } \\
\text { Comparison }\end{array}$} \\
\hline & $M$ & $S D$ & $M$ & $S D$ & $M$ & $S D$ & & \\
\hline Father-child Cohesion & 6.45 & 1.87 & 6.73 & 1.78 & 6.73 & 1.91 & $14.06 * * *$ & $\mathrm{BO}<\mathrm{IO}, \quad \mathrm{P}$ \\
\hline Mother-child Cohesion & 7.22 & 1.61 & 7.39 & 1.53 & 7.39 & 1.54 & $7.51 * *$ & $\mathrm{BO}<\mathrm{IO}, \quad \mathrm{P}$ \\
\hline Marital Cohesion & 6.45 & 1.77 & 6.64 & 1.71 & 6.61 & 1.93 & $6.55 * *$ & $\mathrm{BO}<\mathrm{IO}$ \\
\hline $\begin{array}{l}\text { Power of the Father } \\
\text { over Children }\end{array}$ & 5.20 & 0.86 & 6.56 & 1.71 & 6.54 & 1.73 & $186.50 * * *$ & $\mathrm{BO}<\mathrm{IO}, \quad \mathrm{P}$ \\
\hline $\begin{array}{l}\text { Power of Children over } \\
\text { the Father }\end{array}$ & 5.76 & 1.75 & 5.90 & 1.74 & 6.05 & 1.67 & $16.30 * * *$ & $\mathrm{PO}<\mathrm{IO}<\mathrm{P}$ \\
\hline $\begin{array}{l}\text { Power of the Mother } \\
\text { over the Children }\end{array}$ & 6.77 & 1.41 & 6.84 & 1.36 & 6.77 & 1.42 & n.s. & \\
\hline $\begin{array}{l}\text { Power of Children over } \\
\text { the Mother }\end{array}$ & 5.86 & 1.53 & 6.00 & 1.57 & 6.18 & 1.51 & $27.64 * * *$ & $\mathrm{BO}<\mathrm{IO}<\mathrm{P}$ \\
\hline $\begin{array}{l}\text { Power of the Father } \\
\text { over the Mother }\end{array}$ & 6.17 & 1.72 & 6.25 & 1.71 & 6.21 & 1.75 & n.s. & \\
\hline $\begin{array}{l}\text { Power of the Mother } \\
\text { over the Father }\end{array}$ & 6.33 & 1.59 & 6.44 & 1.58 & 6.52 & 1.59 & $10.13 * * *$ & $\mathrm{BO}<\mathrm{IO}, \quad \mathrm{P}$ \\
\hline
\end{tabular}


A large portion of the participating families owned one dog kept indoors, and this was the first dog the family had owned. From this, we can deduce that interaction between family members became active, with the dog as the medium, resulting in a significant change in family relationships. Moreover, the same family member whose decision it was to own a dog became the main carer for the dog, indicating that the integrity of the attitude of the person who decided to own a dog becoming responsible to care for the dog is an important contributing factor to the changes observed in family relationship.

Regarding the reason for the increase of the children's power over the parents, in most cases, it can be assumed that the dog is of common interest for family members, and becomes the topic of conversation in communication between family members. Meanwhile, collaboration of family members are promoted through activities such as dog-walking. Moreover with regard to the effect of the experience caring for a dog has on the development of children, Mallon (1992) states that children's emotions of solitude are alleviated through caring for an animal, and they recognize friendship and develop responsibility in their actions. Hayashi (1999) states that through interaction with animals such as dogs, children "gain the ability to understand the pain of others" and "develop self-esteem and perseverance". Through interaction with their dog, children learn many things such as being responsible for their actions. This opportunity for growth and development and active interaction between family members are thought to contribute to the increased power of the children in the family.

Here we will discuss the results that show the significant increase of the power of the father over the children. In general, it has been noted that there is less interaction between the father and his children during adolescence than there is between the mother and her children or the mother and the father (Sohgon Akao, 2003). Imai (1986) compiled the basic factors of social power in a parent-child relationship. Factors include referent-expert power which depends on the intellectual ability and the wealth of experience of the influencer and identifying oneself with influencers who possess those qualities, and attraction power which depends on affectionate emotions towards the influencer or the sustenance of relationship with the influencer. Noguchi (2007) indicates that there is a positive correlation between the recognition of the father's referent-expert power and attraction power by his adolescent children and an open, honest communication between the parent and child. Through caring for a dog, the father gained the opportunity to interact with his children, and we can assume that as a result of frequent communication with the dog as the medium, the increase in the father's influence was observed.

We have shown in this research the alterations observed in family structure such as cohesion and power through the ownership of a dog. However, it is not merely the act of keeping a dog that results in changes in family structure, factors such as the environment in 
which the dog is kept need to be taken into consideration for assessment. Moreover, this research had only one member of the family participating, the mother or the father, with no consideration from the other family members' perspective. Following research should target perspectives of multiple members of the family to assess the state of family structure with regard to the ownership of a dog.

\section{Acknowledgements}

This study was supported by DOG FRIENDLY CORP.

\section{References}

Cain, A. (1983). A study of pets in the family system. In Katcher, A. \& Beck, A. (Eds.), New Perspectives on Our Lives with Companion Animals (pp. 72-81). Philadelphia, PA: University of Pennsylvania Press.

Cohen, S. P. (2002). Can pets function as family members? Western Journal of Nursing Research, 24, 621-638.

Froma, W. (2009). Human-animal bonds II: The role of pets in family systems and family therapy. Family Process, 48, 481-499.

Hayasi, Y. (1999). Kennshou Animal Therapy. (Verification of animal therapy). KODANSHA. [ in Japanese ] (林良博 (1999). 検証アニマルセラピー. 講談社.).

Imai, Y. (1986). The bases of social power in the parent-adolescent relationship. Japanese Journal of Social Psychology, 1, 35-41. [in Japanese） (今井芳昭 (1986). 親子関係に おける社会的勢力の基盤. 社会心理学研究,
1, 35-41.).

Mallon, G. P. (1992). Utilization of animals as therapeutic adjuncts with children and youth: A review of the literature. Child and Youth Care Forum, 21, 53-67.

Cabinet Office (2010). Doubutsuaigo nikansuru Yoronnchousa. (The public opinion survey of animal welfare）。［in Japanese］（内閣府 (2010)。動物愛護に関する世論調查.）。 Retrieved January 16, 2014, from http://www8.cao.go.jp/survey/h22/h22-doub utu/index.html.

Noguchi, S. (2007). The study of social power and communications in parent-adolescent relationship. The Japanese Journal of Family Psychology, 21, 95-105. [in Japanese] (野口 修司 (2007)。青年期の親子関係における 社会的勢力とコミュニケーションに関す 万研究. 家族心理学研究, 21, 95-105.).

Noguchi, S. Kozuka, T. Usami, T. \& Wakashima, K. (2009). Development and examination of validity for a new family structure assessment scale "ICHIGEKI". Tohoku University Graduate School of Education Annual Research Report, 58, 247-266. [in Japanese]（野口修司 - 狐塚貴 博 - 宇佐美貴章 - 若島孔文 (2009). 家族 構造測定尺度一ICHIGEKI一の作成と妥 当性の検討. 東北大学大学院教育学研究 科研究年報, 58, 247-266.).

Paul, E. S. \& Serpell, J. A. (1996). Obtaining a new pet dog: Effects on middle childhood children and their families. Applied Animal Behaviour Science, 47, 17-29.

Japan Pet Food Association. (2013). Heisei 25nenn Zennkoku Inunekoshiiku Jittaichousa 
Kekka. (The National survey results of dog cat breeding in 2013). [in Japanese] (ペット フード協会 (2013). 平成 25 年全国犬猫飼 育実態調查結果.). Retrieved January 16, 2014,

from http://www.petfood.or.jp/topics/img/140101. pdf.

Sogon, S. \& Sogon, Akao, Y. (2003). How Youth Evaluates Parents-child Relationships During Their School Age. Human Developmental Research, 17, 1-23. [ in Japanese] (荘厳舜哉・荘峳（赤尾）依子 (2003). 子ども期の回想にみる現代青年の
親子関係. 発達研究, 17, 1-23.).

Yokoyama, A. (1996). Animal Therapy toha nanika. (What is animal therapy) . NHK BOOKS. [in Japanese］(横山章光（1996）. アニマル・セラピーとは何か. NHK 出版.). Wakashima, K. \& Matsui, H. (2006). The 23th Annuual Conference of Japan Academy of Family Psychology, Program \& Abstracts, 51-52. [in Japanese] (若島孔文 - 松井博史 (2006). 家族としての犬一飼い主と犬と の関係について一. 日本家族心理学会第 23 回大会抄録集，51-52.). 